\title{
A DISTINÇÃO ENTRE CORRUPÇÃO PASSIVA E CAIXA DOIS
}

\author{
Beatriz Paiva Nobre* \\ Gustavo СотOMACCI**
}

\section{RESUMO}

O artigo visa abordar as concepções de Corrupção Passiva e Caixa Dois, sendo a Corrupção Passiva prevista no artigo 317 do Código Penal e o Caixa Dois abordado de maneira análoga no artigo 350 do Código Eleitoral. Tais práticas possuem semelhanças no cenário atual, cabendo um estudo específico com a finalidade de distinguir e definir quando devemos tipificar o delito como corrupção e, quando devemos intitular como Caixa Dois. Em síntese, no referido artigo abordaremos o conceito de corrupção, sua origem histórica, o bem jurídico tutelado pelo artigo 317 do Código Penal, bem como a definição de Caixa Dois, sua problemática em campanhas eleitorais e, será feita uma análise acerca do artigo 350 do Código Eleitoral. O estudo abordará também o anteprojeto apresentado pelo Tribunal Superior Eleitoral a fim de revisar os delitos eleitorais e criar previsão específica para o Caixa Dois. Por fim, iremos discorrer sobre a distinção entre os delitos após delação de Emílio Odebrecht, as decisões do STF acerca do tema, bem como a quem compete julgar os delitos quando houver conexão entre corrupção passiva e Caixa Dois.

Palavras-chave: Corrupção passiva. Caixa Dois. Direito Penal. Direito Eleitoral. Política Nacional.

\section{THE DISTINCTION BETWEEN PASSIVE CORRUPTION AND "CAIXA DOIS"}

\section{ABSTRACT}

The article aims to address the concepts of Passive Corruption and Box Two. Since Passive Corruption is provided for in Article 317 of the Penal Code and Caixa Dois is approached in a similar manner in Article 350 of the Electoral Code. Such practices have similarities in the current scenario, with a specific study in order to distinguish and define when we should classify the crime as corruption and, when we should name it as box two. In summary, in that article we will address the concept of corruption, its historical origin, the legal good protected by article 317 of the Penal Code, as well as the definition of box two, its problematic in electoral campaigns, and an analysis will be made about 350 of the Electoral Code. The study will also address the preliminary

* Advogada. Pós-graduanda em Direito Tributário, pelo Instituto Damásio de Direito da Faculdade IBMEC. Bacharel em Direito pela Universidade Metodista do Estado de São Paulo - UMESP.

* Gustavo Cotomacci, professor mestre, orientador no Curso de Direito na Universidade Metodista de São Paulo - UMESP. E-mail: gustavo.cotomacci@metodista.br 
draft presented by the Superior Electoral Court to review electoral offenses and create a specific provision for cashier two. Finally, we will discuss the distinction between the crimes after Emílio Odebrecht's complaint, the STF's decisions on the subject, as well as who is responsible for judging the crimes when there is a connection between passive corruption and box two.

Keywords: Passive Corruption. Box two. Criminal Law. Electoral Law. National policy.

\section{INTRODUÇÃO}

O presente artigo tem por objeto de estudo o crime de Corrupção Passiva, previsto no artigo 317 do Código Penal, bem como a prática corriqueira do Caixa Dois, a fim de analisar as distinções entre ambas as condutas.

O crime de Corrupção Passiva faz parte daqueles praticados por funcionários públicos contra a Administração Pública. Importante ressaltar que, mesmo sendo o Código Penal de 1940, ou seja, trata-se de uma lei com mais de 70 anos, o tema continua sendo atual, devido à sua recorrência, não só no ambiente acadêmico, mas também em noticiários e, debates políticos, motivo pelo qual, necessária a comparação e distinção com o famoso Caixa Dois.

Após o escândalo político conhecido como "Operação Lava Jato", se faz necessária a análise de forma minuciosa da distinção, levando em consideração a menção aos delitos, objeto deste estudo, em muitas delações decorrentes da operação supra.

Tendo em vista a amplitude dos crimes praticados contra a Administração Pública, inicialmente será abordado o crime de Corrupção Passiva na visão geral, discorrendo sobre seu conceito e origem histórica, fundamento jurídico, assim como o bem jurídico tutelado pelo artigo 317 do Código Penal.

Foi ainda analisada sua relação com o Caixa Dois, levando em conta o conceito de tal conduta, a fim de saber se o comportamento é típico ou atípico; qual o conceito atual acerca do delito, a problemática desta conduta em campanhas eleitorais, bem como a ausência de tipificação legal específica para o crime.

Com o objetivo de analisar juridicamente e historicamente, foram selecionados casos que abordam ambas as condutas, com o intuito de desmistificar e diferenciar os 2 crimes, considerando que, o Caixa Dois, como veremos no decorrer do artigo, na corrente majoritária enquadra-se na conduta de falsidade ideológica prevista no art. 350 do Código Eleitoral.

Conforme supracitado, com relação à Corrupção Passiva, trata-se de tema antigo, porém recorrente, motivo pelo qual denota-se sua importância; já a ocorrência do Caixa Dois teve um crescimento importante nos últimos 5 anos, à vista disso, necessário se faz o estudo mais aprofundado de tais práticas, devido à sua habitualidade no cenário atual.

\section{CORRUPÇÃO PASSIVA}

O tópico visa abordar o delito intitulado como Corrupção Passiva desde sua origem histórica e tipificação, fundamento constitucional e, por fim, seu conceito. 
Trata-se de crime disposto no título XI do Código Penal, abordado mais precisamente em seu artigo 317.

A fim de que não restem dúvidas sobre o tema, iremos progredir o estudo discorrendo a princípio sobre sua origem histórica.

\subsection{ORIGEM HistÓRICA}

Partindo do estudo de Jean-Jacques Rousseau ${ }^{1}$ sobre as bases da sociedade, podemos extrair da obra "O Contrato Social" seu pensamento sobre a corrupção. Para ele, tal ato seria inerente à formação da sociedade civil, sendo esta, a responsável pela perversão daquele que vivia em estado de natureza.

A obra citada é antiga, tendo como data de surgimento o ano de 1762, entretanto, conforme Strecker (2010, p. 3), ainda é considerada um marco histórico, pois em pleno século XVIII, "Rousseau já conseguia visualizar a associação entre os homens e a impossibilidade de retornar ao estado de natureza, visto que tal estado acarretaria na inexistência de lei ou moralidade".

Resta claro, tal pensamento não se compara à corrupção nos dias de hoje, entretanto, nos aproxima de suas origens, conforme análise histórica.

Durante a era clássica do Direito Grego ${ }^{2}$, começam a surgir os crimes contra a Administração Pública; naquela época, os delitos também eram praticados pelos funcionários públicos e se assemelhavam ao peculato ${ }^{3}$, abuso de autoridade ${ }^{4}$ e corrupção ${ }^{5}$ - porém, "os gregos prezavam pelo bom funcionamento da atividade estatal, portanto ao tomarem ciência de tais infrações, os praticantes dos atos eram punidos, sendo inclusive a pena de morte uma das penalidades". (ALVES SOBRINHO, 2015, p. 2).

Na Roma Antiga, já era prevista a punição para o crime de corrupção, tendo o Estado poder para apreender o que havia sido pago ao funcionário que praticou o ato.

Apenas com o Renascimento, na Idade Moderna, o tratamento jurídico dos crimes contra a Administração Pública começou a se sistematizar. Com a necessidade da formação de uma estrutura estatal, surgiram funcionários públicos admitidos para esse fim, motivo pelo qual se fez necessário a retomada do rigor na punição da corrupção.

No Brasil, entretanto, a previsão do crime demorou a surgir, visto que em 1603 tivemos a publicação do Livro V do Rei Filipe II, cuja fundamentação se dava

1 Rousseau (1712-1778), filósofo social, teórico político e escritor suíço. Considerado um dos principais filósofos do Iluminismo e um precursor do Romantismo, tendo como principal obra "O Contrato Social.

2 Ocorreu durante os séculos VI e IV a.C.

3 Conforme previsão do artigo 312 do Código Penal, trata-se da apropriação pelo funcionário público de dinheiro, valor ou qualquer outro bem móvel, público ou particular, de que tem a posse em razão do cargo, ou desviá-lo, em proveito próprio ou alheio.

4 Trata-se de crime que irá abranger condutas abusivas de poder (excesso de poder ou desvio de finalidade).

5 Ato ou efeito de corromper alguém ou algo, com a finalidade de obter vantagens em relação a outrem, de maneira ilegal ou ilícita. Posteriormente iremos conceituar com precisão o crime de Corrupção Passiva, objeto de estudo dessa monografia. 
em preceitos religiosos. Em 1830 foi sancionado o Código Criminal do Império do Brasil, inspirado no Código Francês. Este nada previa especificamente acerca dos crimes contra a Administração Pública, entretanto o artigo 101 da Lei já previa crimes visando promessa ou recompensa abordando, portanto, a possibilidade de venda de votos, conforme demonstrado em transcrição do artigo:

Art. 101. Solicitar, usando de promessas de recompensa, ou de ameaças de algum mal, para que as Eleições para Senadores, Deputados, Eleitores, Membros dos Conselhos Geraes, ou das Camaras Municipaes, Juizes de Paz, e quaesquer outros empregados electivos, recaiam, ou deixem de recahir em determinadas pessoas, ou para esse fim comprar ou vender votos. Penas - de prisão por tres a nove mezes, e de multa correspondente à metade do tempo; bem assim da perda do emprego, se delle se tiver servido para commetter o crime. (BRASIL. Lei 16 de dezembro de 1830. Código Criminal).

A tipificação específica do crime, portanto, só teve seu surgimento no Brasil, no Código Penal de 1940, conforme previsto no artigo $317^{6}$ do Decreto-Lei n. 2.848/1940.

\subsection{CONCEITO}

A palavra corrupção tem conceitos variados e estes dependem da perspectiva e objetivo daquele que a define.

Corrupção significa "quebra, decomposição, é o mesmo que depravação, suborno, alteração, sedução". (MATOS; BARBOZA, 2017, p. 3).

Maquiavel, filósofo que buscava compreender e explicar a relação entre o Estado e a política ${ }^{7}$, entende que:

A corrupção decorre primeiramente no povo, na meda em que este deixa de atuar com contundência na esfera pública e passa, num segundo momento, para as instituições, quando estas não visam mais ao interesse público, mas aos desejos privados. Assemelhada a uma doença, a corrupção começa em uma parte do corpo político e, se não for detida, alastra-se por todo ele, levando-o a morte, que no caso, seria a perda da liberdade política na cidade. (MAQUIAVEL, 2007, p. 85).

Segundo Matos e Barboza (2017, p. 5), a “corrupção consiste em um comportamento que não se enquadra aos deveres formais do cargo público, a fim de receber em troca vantagens pecuniárias ou status, tanto em favor próprio como de terceiros (familiares ou amigos próximos) ".

Conforme definição de Blume (2015, p. 1), analisando o sentido amplo, a corrupção pode ser definida como "ato ou efeito de se corromper, oferecer algo para obter vantagem em negociata onde se favorece uma pessoa e se prejudica outra".

6 Solicitar ou receber, para si ou para outrem, direta ou indiretamente, ainda que fora da função, ou antes de assumi-la, mas em razão dela, vantagem indevida, ou aceitar promessa de tal vantagem.

7 Informação extraída da biografia de Nicolau Maquiavel. Disponível no site: https:/ / www.infoescola.com 
Como objeto de estudo, iremos adotar a definição prevista no artigo 317 do Código Penal, in verbis:

Art. 317 - Solicitar ou receber, para si ou para outrem, direta ou indiretamente, ainda que fora da função ou antes de assumi-la, mas em razão dela, vantagem indevida, ou aceitar promessa de tal vantagem: Pena reclusão, de 2 (dois) a 12 (doze) anos, e multa.

Resta claro no dispositivo legal que apenas o funcionário público pode praticar o crime de Corrupção Passiva, sendo necessário então, desmistificar o conceito de funcionário público no Direito Penal, conforme dispõe o artigo 327: "Considera-se funcionário público, para os efeitos penais, quem, embora transitoriamente ou sem remuneração, exerce cargo, emprego ou função pública".

Ao exercer a corrupção, todo o desempenho da função pública é afetado, bem como, o desenvolvimento regular da atividade administrativa, motivo pelo qual, o dispositivo penal busca proteger e amparar o regular funcionamento da Administração Pública, tendo em vista os princípios da probidade e moralidade. Importante ressaltar que tais princípios são regidos pela boa-fé do agente que pratica a conduta.

A corrupção tipificada no Código Penal faz referência a condutas específicas, quais sejam:

Solicitar: Nessa modalidade, o funcionário solicita a vantagem e a vítima, cede por vontade própria, ou seja, inexistem atos praticados por terceiros para que se configure crime, a própria solicitação é o suficiente;

Receber: Para que se configure, se faz necessária a presença de um terceiro, tendo em vista que o agente não só aceita a proposta, mas também recebe uma vantagem indevida. Para a configuração do crime, o oferecimento de vantagem indevida deve existir; sem essa oferta, não é possível falar no recebimento de vantagem.

Aceitar a promessa de recebê-la: nesse caso, basta que o funcionário aceite uma recompensa para configurar a prática do delito; não é necessário que a vantagem indevida seja recebida. Para a configuração do crime é necessária a existência da "promessa de vantagem indevida a funcionário público". (CAPEZ, 2017, p. 442).

Conforme demonstrado nas três hipóteses, o objeto material do crime é a vantagem indevida, conforme Fernando Capez. (2017, p. 443): “[...] pode ser de cunho patrimonial, moral, sentimental, sexual etc. Assim, pode o funcionário, por exemplo, solicitar favores sexuais em troca da prática ou abstenção de um ato de ofício".

Cabe ressaltar que a vantagem deve ser indevida, ou seja, não autorizada legalmente. Caso esse requisito não seja observado, estaremos diante de um fato atípico.

O elemento subjetivo do tipo é o dolo, consubstanciado na vontade livre e consciente de praticar a ação. O funcionário ao atuar deve ter ciência de que tal vantagem não lhe é devida.

Com relação ao sujeito ativo, importante ressaltar o entendimento de Fernando Capez: 
Trata-se de crime próprio, portanto só pode ser cometido por funcionário público em razão da função (ainda que esteja fora dela ou antes de assumi-la). Nada impede, contudo, a participação do particular, ou de outro funcionário, mediante induzimento, instigação ou auxílio. $\mathrm{O}$ particular que oferece ou promete vantagem indevida ao funcionário público responde pelo crime de corrupção ativa (CP, art. 333) e não pela participação no crime em estudo. Trata-se de exceção à regra prevista no art. 29 do CP. (CAPEZ, 2017, p. 444).

Como o objeto da discussão é um crime formal, definido por Fernando Capez (2014, p. 282) como o delito que não exige a produção do resultado para sua consumação, o resultado, embora possível, é irrelevante para consumação da infração penal.

No crime em apreço, a consumação ocorre no momento da solicitação, recebimento ou do aceite da promessa, assim como no crime de concussão (outra modalidade de delito praticado contra a Administração Pública) é admitido o flagrante esperado, este irá ocorrer no momento do recebimento da vantagem indevida.

\section{TIPIFICAÇÃO}

O objetivo deste tópico é adentrar de forma analítica na tipificação do delito, ou seja, analisar de forma minuciosa sua evolução no Brasil, bem como, qual o bem jurídico tutelado pelo dispositivo em questão, qual seja, o artigo 317 do Código Penal Brasileiro.

\subsection{EVOLUÇÃO DA TIPIFICAÇÃO DO CRIME}

Diante dos fatos expostos até o momento, podemos concluir que o delito da Corrupção não é recente. Foi citado de maneira introdutória no primeiro dispositivo penal aplicado no Brasil. (Livro V das Ordenações Filipinas de 1603).

No diploma legal em questão, o delito mais próximo do tipo penal abordado no artigo era o delito praticado por Oficial de Justiça ou por aqueles que subtraíssem qualquer coisa do rei. A pena prevista era a perda do cargo e o pagamento de um múltiplo valor recebido, existindo ainda, a possibilidade da perda de bens. (TEIXEIRA, 2010, p. 27).

O Livro V das Ordenações Filipinas vigorou por mais de dois séculos, sendo revogado com a promulgação do Código Criminal do Império, em 16 de dezembro de $1830^{8}$. Tal dispositivo apresentou uma evolução, especificando, inclusive, o delito de Concussão em seus artigos 135 e 136.

Com a proclamação da República, adveio uma fase de crescimento para o Estado, conforme Sergio Habib (1994, p. 76), e pessoas passaram a ser nomeadas para cargos públicos como moeda de troca pelo apoio dado àqueles eleitos, ou seja, o funcionalismo público passou a ser um ambiente propício à corrupção.

8 BRASIL. Lei 16 de dezembro de 1830. Código Criminal do Império.

9 Exigir, para si ou para outrem, direta ou indiretamente, ainda que fora da função, ou antes, de assumi-la, mas em razão dela, vantagem indevida. (art. 316, do Código Penal). 
Devido a essa evolução, principalmente no aspecto político, em 11 de outubro de 1890, foi editado o Decreto 847, que reformava o regime penal e introduzia o Código Penal dos Estados Unidos do Brasil ${ }^{10}$. Este decreto, entretanto, estava eivado de erros, ocasionando assim a promulgação de diversas legislações extravagantes. Diante disso, em 1940, foi promulgado o novo Código Penal, com vigência estabelecida para o dia 01 de janeiro de 1942. (D'OLIVEIRA, 2014, p. 36).

É na redação do Código Penal de 1940 que encontramos o conceito de Corrupção Passiva, mais precisamente, em seu artigo 317, inserindo-se em título integralmente dedicado aos crimes praticados contra a Administração Pública.

\subsection{BeM juRídico tutelado Pelo artigo 317 do Código Penal}

A priori, é pertinente especificar o conceito de bem jurídico, a fim de que este não se confunda com a definição do objeto material do delito, que nada mais é do que o próprio objeto sobre o qual a conduta criminosa recai concretamente.

Franz Von Liszt (2006, p. 94) aduz a seguinte definição para bem jurídico:

O bem jurídico, objeto da proteção do Direito, em última análise é sempre a existência humana nas suas diversas formas e manifestações. Ela é que é o bem jurídico, isto é, o centro de todos os interesses juridicamente protegidos. Mas a existência humana aparece-nos como existência do homem considerado em sua individualidade ou como existência dos membros da comunhão na sua coletividade. Todos os interesses atacados pelo crime e protegidos pelo Direito Penal se distinguem consequentemente em bens do indivíduo e em bens da coletividade.

O que pode ser extraído do conceito apresentado é que o legislador, ao aplicar uma pena, deverá verificar a lesão ao bem jurídico, sendo vedada a aplicação de acordo com o seu interesse pessoal.

Agora, passemos a analisar especificamente o bem jurídico tutelado pelo artigo 317 do Código Penal. Os crimes previstos no Código Penal ofendem a atuação administrativa prevista na Constituição Federal, o que faz com que alguns doutrinadores concluam que o bem jurídico tutelado pelo artigo 317 do Código Penal é a própria Administração Pública.

Para Nucci (2016, p. 317), por exemplo, o bem jurídico previsto no artigo 317 do Código Penal é a Administração Pública, tanto no aspecto patrimonial como no moral.

Na visão de Fazzio Júnior (2001, p.77), tais crimes dirigem-se sempre contra atividade administrativa que concretiza a função pública. Este é um bem jurídico administrativo de forma constante.

Matos e Barboza (2017, p. 5) entendem que o bem jurídico atingido é o decoro da Administração, ou seja, seus princípios e a confiança que a sociedade deposita no órgão, tendo como condição a legalidade de seu exercício e, como consequência, a sua credibilidade.

10 BRASIL. Decreto 847/1890. Decreto elaborado por Marechal Deodoro da Fonseca, durante Governo Provisório. 
Podemos extrair de todos os conceitos citados, que a tipificação descrita no artigo 317 do Código Penal tem por objetivo tutelar a Administração Pública, para que esta tenha um funcionamento adequado. Portanto, comportamentos que violem os preceitos fundamentais elencados no artigo 37 da Constituição Federal, implicam no reconhecimento de que a Administração Pública teve sua atividade violada, devendo-se punir o Funcionário Público que violou a regular conduta.

\section{CAIXA DOIS}

Conduta ilegal exercida pela maioria das vezes no meio eleitoral, embora inexista tipificação expressa para o delito, a infração já encontra-se sendo punida, tendo em vista as notícias recorrentes sobre favorecimento ilícito envolvendo muitos partidos brasileiros.

No caso, a conduta fez com que novos personagens surgissem no contexto nacional, quais sejam os "doleiros ${ }^{11 "}$ e os "laranjas ${ }^{12 "}$. Diante disso, necessário analisar as características e singularidades do delito em questão.

\subsection{Distinção de CAIXA DoIS E A RELAÇÃo COM O PRINCíPIO DA LEGALIDADE}

Caixa Dois pode ser definido como uma "prática financeira ilegal, que consiste em não registrar determinadas entradas ou saídas de um fluxo de caixa, criando um caixa paralelo". (CASTILHOS, 2017, p. 4).

O ministro Luiz Fux (2012, p. 1525), ao proferir seu voto na Ação Penal (AP) 470/STF ${ }^{13}$, definiu Caixa Dois como:

[...]prática de manutenção ou movimentação de recursos financeiros não escriturais ou falsamente escriturados na contabilidade de pessoas jurídicas, as mais diversas, como associações, fundações, sociedades comerciais e partidos políticos ${ }^{14}$.

Na visão de Luiz Flávio Gomes (2015, p. 1), o Caixa Dois em campanhas eleitorais se adapta à conduta prevista no artigo 350 do Código Eleitoral, que dispõe o seguinte:

Art. 350. Omitir, em documento público ou particular, declaração que dele devia constar, ou nele inserir ou fazer inserir declaração falsa ou diversa da que devia ser escrita, para fins eleitorais:

Pena - reclusão até cinco anos e pagamento de 5 a 15 dias-multa, se o documento é público, e reclusão até três anos e pagamento de 3 a 10 dias-multa se o documento é particular.

11 Os doleiros surgem sempre que o dinheiro proveniente de caixa dois precisa ser enviado ao exterior (paraísos fiscais).

12 Na linguagem popular, o termo "laranja" passou a ser utilizado para se referir a um indivíduo que empresta seu nome - muitas vezes sem saber - para transações financeiras e comerciais criminosas, ocultando a identidade do verdadeiro responsável pelo crime.

13 Ação Penal conhecida como "Ação Penal do Mensalão".

14 Voto de Ministro Luiz Fux na AP 470/STF. Página 1.525. Acórdão proferido em 17/12/2012. Disponível em: https://www.conjur.com.br/dl/ap470.pdf 
Parágrafo único. Se o agente da falsidade documental é funcionário público e comete o crime prevalecendo-se do cargo ou se a falsificação ou alteração é de assentamentos de registro civil, a pena é agravada.

Caso não venha a ser praticado no âmbito eleitoral, a conduta será tipificada no artigo 299 do Código Penal, que também aborda a falsidade ideológica, como veremos em subcapítulo específico sobre o artigo 350 do Código Eleitoral.

Por fim, Caixa Dois pode ser traduzido também, na visão de Schlickmann e Lubke (2008, p. 4), "como manobras contábeis realizadas com fim de obter, esconder, manipular ou utilizar recursos, sejam estes financeiros ou não, de forma a ferir as normas estabelecidas para a contabilidade das agremiações partidárias".

Partindo desses conceitos, é passível o entendimento de que o Caixa Dois atinge diretamente a disputa entre os candidatos, tendo em vista a entrada de recursos financeiros de modo ilegal.

Nesse sentido, em uma eleição as relações políticas devem basear-se no princípio da Reserva Legal ${ }^{15}$. Neste passo, Miguel Reale Júnior (2000, p. 166) entende que o propósito do princípio da Legalidade ${ }^{16}$ é proteger o cidadão face ao Estado, sendo considerado uma consequência obrigatória do pensamento democrático.

\subsection{PRoblemática do CaIXA DOIS EM CAMPANHAS ELEITORAIS}

Carlos Joel Carvalho de Formiga Xavier (2010, p. 72), a fim de obter título de Mestre em Ciências Políticas pela Universidade de São Paulo, se aprofundou no tema e realizou um estudo sobre a corrupção política e o Caixa Dois de campanha no Brasil, definindo o Caixa Dois de campanha como "recursos materiais sejam eles financeiros ou de outra natureza, utilizados para fazer frente aos gastos e necessidades de campanha, cuja origem não seja declarada à justiça eleitoral na prestação de contas exigidas pela lei"17.

Em nosso ordenamento, podemos encontrar a tipificação do delito intitulado como Caixa Dois, na Lei 7.492/86 (Lei de Crimes Contra o Sistema Financeiro Nacional) e na Lei 8.137/90 (Lei de Crimes Contra a Ordem Tributária, Econômica e Contra as Relações de Consumo).

A Lei de crimes contra o sistema financeiro nacional prevê em seu artigo 11 a seguinte definição:

Art. 11. Manter ou movimentar recurso ou valor paralelamente à contabilidade exigida pela legislação:

Pena: reclusão, de 1 (um) a 5 (cinco) anos, e multa (BRASIL, Crimes contra o sistema financeiro nacional, Lei $\mathrm{n}^{\mathrm{o}}$ 7.492/1986).

Já a Lei 8.137/90, que aborda os Crimes Contra a Administração Tributária, Econômica e Contra as Relações de Consumo, prevê em seu artigo $2^{\circ}$ a supressão

15 Só será considerada infração penal a conduta prevista como tal em Lei.

16 Previsto no Código Penal e na Constituição Federal, é uma forma de garantia dada pela Constituição a todo e qualquer particular.

17 XAVIER, C. J. C. F. A corrupção política e o caixa 2 de campanha no Brasil. 2010. Disponível em: http://www.teses.usp.br/teses/disponiveis/8/8131/tde-26092011-135010/pt-br.php 
ou redução de tributo ou contribuição social e qualquer acessório, sendo que, na visão de Fábio Dutra, Paulo Guimarães e Renan Araújo (2018, p. 5) as condutas abordadas nesse artigo são menos gravosas e, até por isso, receberam sanção mais branda. Trata-se de crime próprio em que o sujeito ativo é o contribuinte ou o responsável (pessoa que possui uma relação pessoal e direta ou de responsabilidade que gere um vínculo com a situação que deu origem ao fato gerador) em relação à obrigação tributária.

$\mathrm{O}$ inciso $\mathrm{V}$ do artigo $2^{\circ}$, do mesmo diploma normativo dispõe que constitui crime contra a ordem tributária, "utilizar ou divulgar programa de processamento de dados que permita ao sujeito passivo da obrigação tributária possuir informação contábil diversa daquela que é, por lei, fornecida à Fazenda Pública". (BRASIL, Crimes Contra a Ordem Tributária, Lei 8.137/1990).

Nesse sentido, nota-se que os dispositivos mencionados se enquadram em fraude escritural, tendo como propósito a falsificação da realidade. Na visão de Piazer (2015, p. 37), "essa conduta torna inviável a atuação dos órgãos de controle ao tentarem fiscalizar e rastrear os valores movimentados indevidamente. Ainda assim, em matéria eleitoral especificadamente, a expressão caixa dois não se encontra positivada".

Essa lacuna faz com que atualmente os fatos descritos como Caixa Dois em campanhas eleitorais, sejam enquadrados como crime de falsidade ideológica, tipificado no artigo 299 do Código Penal. Tal situação é, também, prevista de maneira específica no artigo 350 do Código Eleitoral, sempre que estiver relacionada a processo político-eleitoral.

Ressalta-se que a expressão Caixa Dois surge para confrontar o caixa um, este concernente à "provisão de recursos provenientes da iniciativa privada, cujo controle de movimentação é disponibilizado à Justiça Eleitoral, por meio do instituto da prestação de contas". (PIAZER, 2015, p. 37).

Resta claro que a prática do delito supracitado fere o regular prosseguimento das eleições partidárias; no mais, na obra "Temas de Direito Eleitoral no Século XXI", o Procurador Regional Eleitoral Carlos Augusto da Silva Cazarré (2012, p. 464) traz a seguinte observação:

A Constituição Federal, já no seu art. $1^{\circ}$, ao estabelecer os seus princí-
pios fundamentais, instituiu uma República Federativa que se constitui
em Estado Democrático de Direito, fundamentado, entre outros valores,
no pluralismo político, e que tem como fonte única do poder político o
povo, que o exerce por meio de seus representantes ou diretamente (art.
$1^{\circ}$ ). Essa disposição aparentemente singela traz, em virtude, profundas
consequências para a disciplina do acesso ao poder político e, logo, para
o Direito Eleitoral, em todos os seus aspectos, inclusive o penal.

Partindo dessa premissa, os tipos penais buscam proteger categoricamente copiosos aspectos do processo eleitoral, com a finalidade de garantir a efetividade das normas que visam obter a mais legítima manifestação de vontade popular. (CAZARRÉ, 2012, p. 469). A fim de garantir essa efetividade, é permitida a aplica- 
ção de sanções penais quando a conduta for tipificada como lesiva ao bem jurídico, visando à garantia do regime democrático.

Por fim, antes de adentrarmos especificamente na análise do artigo 350 do Código Eleitoral, necessário buscar a definição de crime eleitoral, que, na visão de Ponte (2016, p. 19), trata-se de:

Condutas descritas na lei como atentatórias à lisura, transparência, correta formação e desenvolvimento do processo eleitoral, que tem como resposta penal destinada a seus responsáveis a imposição da correspondente sanção penal, sem prejuízo da suspensão dos direitos políticos.

Entende-se, portanto, por esta definição supra que, crimes eleitorais são todas as condutas que atentem contra a transparência e o regular prosseguimento do processo eleitoral, devendo, à vista disso, haver punição para tais situações.

Análise acerca do crime eleitoral previsto no artigo 350 do Código Eleitoral

A Lei 4.737/1965, recepcionada pela Constituição Federal de 1988, que institui o Código Eleitoral em seu artigo 350, prevê o seguinte:

Art. 350. Omitir, em documento público ou particular, declaração que dele devia constar, ou nele inserir ou fazer inserir declaração falsa ou diversa da que devia ser escrita, para fins eleitorais:

Pena - reclusão até cinco anos e pagamento de 5 a 15 dias-multa, se o documento é público, e reclusão até três anos e pagamento de 3 a 10 dias-multa se o documento é particular.

Parágrafo único. Se o agente da falsidade documental é funcionário público e comete o crime prevalecendo-se do cargo ou se a falsificação ou alteração é de assentamentos de registro civil, a pena é agravada. (BRASIL, Código Eleitoral, Lei 4.737/96).

Ressalta-se, como mencionado anteriormente no subcapítulo 4.1, que o referido artigo tipifica a mesma conduta prevista no artigo 299 do Código Penal, conforme verifica-se a seguir:

Art. 299 - Omitir, em documento público ou particular, declaração que dele devia constar, ou nele inserir ou fazer inserir declaração falsa ou diversa da que devia ser escrita, com o fim de prejudicar direito, criar obrigação ou alterar a verdade sobre fato juridicamente relevante:

Pena - reclusão, de um a cinco anos, e multa, se o documento é público, e reclusão de um a três anos, e multa, se o documento é particular.

Parágrafo único - Se o agente é funcionário público, e comete o crime prevalecendo-se do cargo, ou se a falsificação ou alteração é de assentamento de registro civil, aumenta-se a pena de sexta parte. (BRASIL, Código Penal).

Inexistem dúvidas quanto à similitude dos dispositivos mencionados, ora, ambos consistem na prática de ato fraudulento. Necessário observar, porém, sempre que aplicada a falsidade eleitoral prevista no artigo 350 da Lei 4.737/65, afasta- 
-se a imposição do tipo penal descrito no artigo 299 do Decreto-Lei 2.848/40, tendo em vista tratar-se de crime de falsidade ideológica transplantado para a órbita eleitoral, de acordo com Suzana de Camargo Gomes (2008, p. 341).

Analisando minuciosamente o artigo 350 do Código Eleitoral, nota-se que o seu objetivo é tutelar a autenticidade dos documentos, portanto, a falsidade em questão é do tipo ideológica. Nessa linha, segue entendimento:

\begin{abstract}
A falsidade que cogita a norma penal não é de forma, mas de conteúdo. Não há que se falar em adulteração, rasura, inclusão ou retirada de letras ou algarismos do documento. Ocorre, isto sim, uma menção inverídica retratada no documento ou, como ressalta Sylvio do Amaral, "há, apenas, uma mentira reduzida a escrito, através do documento que, sob o aspecto material, é de todo verdadeiro, isto é, realmente escrito por quem seu teor indica". No falso ideal, o agente forma um documento até então inexistente, para, através dele, fraudar a verdade. O documento assim elaborado pelo falsificador é extrinsecamente verdadeiro, pois quem o escreve é efetivamente quem aparece no texto como seu autor; o que há nele de inverídico é o conteúdo ideológico pois seu texto é falto ou omisso em relação à realidade que devia consignar. (GOMES, 2008, p. 342).
\end{abstract}

Ademais, como o artigo 350 prevê o delito de falsidade ideológica é importante ressaltar a admissibilidade da figura omissiva ou comissiva. Será omissiva, quando o agente deixar de prestar informação quando era obrigado a fazê-lo, e comissiva quando inserir ou fazer inserir declaração falsa ou diversa daquela que deveria constar no documento. (GONÇALVES, 2015, p. 123).

Com relação às condutas comissivas de inserir ou fazer inserir, estas são abordadas da seguinte forma:

Inserir significa incluir, incorporar, expressar no documento declaração inverídica ou de conteúdo diverso daquele que deveria ser mencionado. Já fazer inserir pressupõe a ação de fazer gravar, inscrever, o que denota a existência de um autor intelectual e de um autor material ${ }^{18}$ do crime, este último somente podendo ser assim qualificado se tiver consciência da ilicitude do atuar. Caso contrário, será mero instrumento do agente, não havendo que se falar tenha ele cometido o delito. (GOMES, 2008, p. 343).

Além disso, trata-se de crime comum, ou seja, pode ser praticado por qualquer pessoa, porém, haverá um aumento de pena no instante em que o sujeito ativo for funcionário público e praticar o crime valendo-se do cargo ${ }^{19}$.

Sobre o tema, segue entendimento do Tribunal Superior Eleitoral ao julgar Habeas Corpus impetrado a fim de obter o trancamento da ação penal:

18 Ao autor material, faz-se necessária a consciência da ilicitude, elemento essencial para caracterização do dolo, ou seja, se provocado por terceiro dolosamente, somente o terceiro responderá pelo crime.

19 Vide parágrafo único do artigo 350 do Código Eleitoral. 
HABEAS CORPUS. ELEIÇÕES 2012. PREFEITO. DENÚNCIA. ART. 350 DO CÓDIGO ELEITORAL. DECLARAÇÃO FALSA. NOTAS FISCAIS. ART. $1^{\circ}$, I, DO DL 201/67. DESVIO DE RENDAS PÚBLICAS. GRAVAÇÃO AMBIENTAL. LICITUDE. ORDEM DENEGADA. 1. Os pacientes, Prefeito e Vice-Prefeito de Pirangi/SP, foram denunciados por desviar recursos públicos da área de educação, no total de $\mathrm{R} \$$ 4.741,00, simulando ou superfaturando notas fiscais de serviços de empresa de autopeças contratada pela Prefeitura, com objetivo de financiar sua campanha à reeleição mediante "caixa dois" (arts. 350 do Código Eleitoral e $1^{\circ}$, I, do DL 201/67). Das gravações que embasaram a ação penal. 1. A denúncia encontra-se instruída com gravações ambientais realizadas por Jeovane Correa (réu e funcionário da empresa) em que alguns dos denunciados descrevem o modus operandi do esquema e a destinação dos recursos para churrasco de campanha. 2. Os impetrantes aduzem que a prova é ilícita e citam o que decidido no AgR-REspe 55364, Rel. Min. Luciana Lóssio, DJE de 11.9.2014, que cuida de Ação de Investigação Judicial Eleitoral (AIJE) com base nos mesmos fatos. [...] Do trancamento da ação penal. 1 . O trancamento de ação penal por meio de habeas corpus é medida de índole excepcional, apenas admitido em hipóteses em que se denote, de plano, falta de justa causa, inexistência de aspectos indiciários demonstrativos da autoria e da materialidade do delito ou, ainda, presença de causa excludente de punibilidade. Precedentes. 2. No caso, não há constrangimento ilegal, eis que a denúncia atende aos arts. 41 do CPP e 357, § $2^{\circ}$, do Código Eleitoral. São descritos na peça acusatória fatos que configuram, em tese, os crimes dos arts.

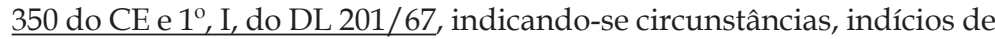
autoria e individualização de condutas. Conclusão. 1. Ordem denegada (grifo nosso).

(Habeas Corpus n 21460, Acórdão, Relator(a) Min. Herman Benjamin, Publicação: DJE - Diário de justiça eletrônico, Data 03/10/2016, Página 31202

Na visão de Leonardo Schmitt de Bem e Mariana Garcia Cunha (2011, p. 288), para que o Tribunal Superior Eleitoral entenda pela não caracterização do delito, a declaração com fins eleitorais deve ser feita por terceiros.

É possível extrair com base nas informações trazidas à baila, que, em se tratando da hipótese de falsidade ideológica prevista no Código Eleitoral, o documento em questão tem veracidade, assim como o sujeito tem competência para expor os fatos ou elaborar declaração. O único problema está na afirmação, tendo em vista sua inverdade (omissão ou inserção de dados).

No mais, caso o ato não seja praticado com fins eleitorais, estaremos diante da hipótese prevista no artigo 299 do Código Penal, que, apesar da redação idêntica, dispensa a finalidade específica. (BEM; CUNHA, 2011, p. 289).

20 BRASIL. Tribunal Superior Eleitoral. HC no 0000214-60.2015.6.00.000, acórdão de 03/10/2016, da relatoria do ministro Herman Benjamin. 


\section{ANTEPROJETO DE REVISÃO DOS DELITOS ELEITORAIS APRE- SENTADO PELO TRIBUNAL SUPERIOR ELEITORAL}

Diante da inexistência de tipificação específica para o delito de Caixa Dois, o Tribunal Superior Eleitoral, por meio de inciativa do ministro Carlos Veloso, apresentou ao Congresso Nacional uma proposta de alteração da legislação eleitoral em vigor. (AGUIAR, 2005).

Uma das sugestões diz respeito à criminalização do Caixa Dois em campanha eleitoral, prevista no artigo 339 do anteprojeto de revisão dos delitos eleitorais, que dispõe:

Art. 339. Manter ou movimentar recurso ou valor paralelamente à contabilidade exigida pela legislação para a escrituração contábil de partido político e relativa ao conhecimento da origem de suas receitas e a destinação de suas despesas:

Pena - reclusão, de 3 (três) a 8 (oito) anos, e multa, além da perda dos recursos ou valores.

$\S 1^{\circ}$. A pena será aumentada quando se tratar de recurso ou valor referente à prestação de contas de campanha eleitoral.

$\S 2^{\circ}$. Incorrerá na mesma pena quem receber recurso ou valor proveniente de atividade ilícita ou não declarado pelo doador ao órgão competente ${ }^{21}$.

Nesse sentido, o bem jurídico em questão é a probidade das contas eleitorais e partidárias, medida extremamente necessária, levando em consideração a exigência de transparência e moralidade face aos acontecimentos vivenciados no âmbito político partidário, "a fim de resguardar a integridade das instituições constitucionalmente necessárias à democracia representativa e garantir-se a lisura do processo eleitoral". (SCHLICKMANN; LUBKE, 2008, p. 7).

Inexistem dúvidas que a tipificação do artigo supra traduz a expressão conhecida como "Caixa Dois", diante do que Denise Goulart e Heloísa Helena fazem a seguinte confrontação com a Lei 9.096/95 (trata sobre os partidos políticos):

[..] a Lei n. 9.096, de 19.9.1995, traz normas específicas para a arrecadação e a aplicação de recursos pelos partidos políticos, prevendo vedações à captação de doações de determinadas fontes e estabelecendo regras para a utilização de recursos do Fundo Partidário, objetivando, por meio de suas prestações de contas anuais à Justiça Eleitoral, permitir o conhecimento de suas receitas e a destinação de suas despesas. Assim, a manutenção ou a movimentação de recursos por partido político fora da escrituração contábil fiscalizada pela Justiça Eleitoral configuraria a hipótese prevista no caput do dispositivo em comento, mesmo que, em tese, tal manutenção ou movimentação de recursos pudesse vir a ser considerada lícita se integrasse a contabilidade regular da agremiação. Isso porque a configuração da conduta típica, nesse caso, independeria da natureza dos recursos mantidos ou movimentados, sendo reprovável, tão-somente, a existência dessa contabilidade paralela (SCHLICKMANN; LUBKE, 2008, p. 8). (Grifo nosso).

${ }^{21}$ ASIL. Tribunal Superior Eleitoral. Anteprojeto de Revisão dos Delitos Eleitorais. 
É clara, no caso em tela, a necessidade de tipificação de maneira precisa para o delito de Caixa Dois, tendo em vista as lacunas previstas tanto no Código Eleitoral, como na Lei 9.096/95.

No projeto em questão, os sujeitos ativos seriam os dirigentes partidários, ou seja, os líderes dos partidos políticos, além dos tesoureiros, pois ambos são responsáveis por gerenciar as contas do partido.

Diferente do crime de falsidade ideológica previsto no artigo 350 do Código Eleitoral, o artigo 339 do anteprojeto prevê uma pena mais rigorosa, qual seja, reclusão de 3 (três) a 8 (oito) anos cominada com a perda de recursos ou valores.

Ressalta-se, entretanto, as causas de aumento de pena, dispostas nos parágrafos $1^{\circ}$ e $2^{\circ}$ do artigo mencionado. Neste caso, a pena será aumentada quando se tratar de recurso ou valor referente à prestação de contas de campanha eleitoral e incorrerá na mesma pena quem receber recurso ou valor proveniente de atividade ilícita.

Com as penas mais rígidas presume-se a redução da prática do delito, tendo em vista conduta tipificada em lei.

Ademais, necessário frisar também que o anteprojeto, além de prever tipificação para o Caixa Dois, propõe a criminalização da conduta concernente à omissão na prestação de contas, conforme dispõe o artigo 340:

Art. 340. Omitir 22 , na prestação de contas, recurso ou valor relativo à receita ou despesa de partido político ou de campanha eleitoral, ou outra informação exigida pela Justiça Eleitoral:

Pena - reclusão, de 1 (um) a 4 (quatro) anos, e multa ${ }^{23}$.

Assim como o artigo 339, o tipo penal busca proteger a integridade das contas dos partidos políticos e de suas campanhas eleitorais respectivamente.

Na visão de Schlickmann e Lubke, as propostas trazidas à baila vêm com o objetivo de suprir carências existentes no processo eleitoral:

Tanto em relação a este crime, quanto em relação ao anterior, constata-se que as propostas constantes no anteprojeto vêm suprir carência vivenciada pelos operadores do processo eleitoral, que, muitas vezes, observam a imposição de diversas obrigações pela legislação atinente às contas eleitorais e partidárias sem, contudo, restarem determinadas sanções pelo descumprimento dessas obrigações, o que leva partidos, candidatos e comitês financeiros de campanha eleitoral a comportar-se de forma a ignorar os ditames dessas normas, conduzindo à sensação de impunidade generalizada. (SCHLICKMANN; LUBKE, 2008, p. 10).

Com relação ao sujeito ativo, no delito em questão (artigo 340), podem ser caracterizados como sujeitos o candidato e também o administrador financeiro de sua campanha, respondendo de forma solidária pela veracidade das informações financeiras e contábeis relativas à campanha. Além destes, podem ser incursos na

${ }^{22}$ Deixar de submeter à Justiça Eleitoral informações relativas às contas do partido político.

23 BRASIL. Tribunal Superior Eleitoral. Anteprojeto de Revisão dos Delitos Eleitorais. 
sanção, os membros do comitê financeiro e também os dirigentes do partido político, pois respondem pelas contas das agremiações partidárias - porquanto, todas as figuras citadas têm o dever legal de prestar contas à Justiça Eleitoral, seja por conta da campanha eleitoral, seja anualmente por obrigação imposta aos partidos. (SCHLICKMANN; LUBKE, 2008).

No mais, trata-se de crime omissivo próprio ${ }^{24}$, portanto, incabível tentativa. Entretanto, existe uma controvérsia com relação à sua consumação, vez que os partidos constantemente deixam de apresentar todos os dados relativos à conta, no momento de sua prestação, complementando as informações, porém, quando solicitado esclarecimentos pela Justiça Eleitoral, motivo pelo qual gera-se o questionamento: seria a omissão de dados na prestação inicial suficiente para a consumação do crime ou se daria em momento posterior? Até o momento, inexiste entendimento acerca do tema.

É prevista a pena de reclusão de 1 a 4 anos e multa, inexistindo especificação de valor mínimo ou máximo.

Embora até o momento a posição exposta no artigo tenha sido a favor, levando em consideração posicionamento de Schlickmann e Lubke (2008), importante mencionar a existência de advogados contrários à tipificação específica do delito Caixa Dois, por entender que a conduta se adequa ao crime intitulado como falsidade ideológica.

Luiz Flávio Gomes (2015, p. 2), por exemplo, afirma que o Caixa Dois é crime, "tratando-se, no entanto de uma forma de falsidade ideológica, estando, portanto, previsto por analogia, no artigo 350 do Código Eleitoral”. Entretanto, o penalista reconhece, por outro lado, a inexistência de crime específico para o Caixa Dois no ordenamento jurídico-penal.

Na visão de Cazarré (2012), a jurisprudência majoritária criou uma resistência à tipificação, argumentando que para sua configuração se faz necessário uma finalidade exclusivamente eleitoral, entendendo que a falsa declaração na prestação de contas quando apresentada após a eleição, não causaria interferência direta nas fases do processo eleitoral e seu consequente resultado, motivo este pelo qual se afasta a incidência do artigo 350 do Código Eleitoral, podendo aplicar a falsidade ideológica prevista no Código Penal, mais precisamente em seu artigo 299.

Importante citar, no entanto, as atuais mudanças com relação ao julgamento de crimes eleitorais, conforme veremos no item a seguir. Por ora, a fim de corroborar com o exposto, o Tribunal Superior Eleitoral ao julgar o Habeas Corpus 000799457.2014.6.19.0000 em 10/02/2015, entendeu o seguinte:

HABEAS CORPUS. IMPETRAÇÃO CONTRA ACÓRDÃO DE TRE, PROFERIDO EM RECURSO EM SENTIDO ESTRITO, QUE DETERMINA O RECEBIMENTO DE DENÚNCIA. FALSIDADE IDEOLÓGICA ELEITORAL (CE, ART. 350). INSERÇÃO DE ASSINATURAS FALSAS EM LISTA DE APOIAMENTO PARA A OBTENÇÃO DE CERTIDÃO EM CARTÓRIO ELEITORAL, COM FINALIDADE DE POSTERIOR

\footnotetext{
24 Delitos de mera conduta, existe apenas a omissão de um dever de agir.
} 
REGISTRO DE PARTIDO POLÍTICO. CONDUTA FORMALMENTE TÍPICA. ORDEM DENEGADA.

1. A conduta de fazer constar assinaturas falsas em lista de apontamento apresentada a cartório eleitoral preenche formalmente o elemento objetivo do tipo penal da falsidade ideológica eleitoral (CE, art. 350). 2. Dado que a inserção das declarações falsas teria por objetivo, segundo a denúncia, a expedição de certidão do cartório eleitoral, para posterior obtenção de registro de partido político, há, em princípio, especificação dos "fins eleitorais" da conduta. Indicação, em tese, do elemento subjetivo especial exigido pelo tipo penal. [...] 4. O trancamento da ação penal pela via do habeas corpus é medida excepcional, somente admitida quando se constata, de plano, a imputação de fato atípico, a ausência de indícios de autoria e de materialidade do delito ou, ainda, a extinção da punibilidade, hipóteses não verificadas no caso concreto. 5. Ordem denegada (grifo nosso).

(TSE - HC: 0007994572014619000 CABO FRIO - RJ, Relator: Min. Maria Thereza Rocha de Assis Moura, Data de Julgamento: 10/02/2015, data de publicação: DJE - Diário de Justiça Eletrônico, tomo 45. Data: 06/03/2015, página 61) $)^{25}$.

Fica claro no julgamento do Habeas Corpus a importância da finalidade eleitoral, característica essa que vem sendo mencionada, pois caso seja confirmada, independentemente de tipificação específica para o delito de Caixa Dois, inexistem dúvidas quanto ao julgamento do delito na Justiça Eleitoral, como falsidade ideológica prevista no artigo 350 do Código Eleitoral.

\section{DISTINÇÃO DOS CRIMES DE CORRUPÇÃO PASSIVA E CAIXA DOIS}

Face ao exposto, podemos entender que nem todo delito cometido por funcionário público será, necessariamente, tipificado como Corrupção Passiva, previsto no artigo 317 do Código Penal.

Nos últimos tempos, o tema em questão passou a ter maior destaque, mais precisamente após a delação premiada de Emilio Odebrecht, momento em que veio à tona a dificuldade em distinguir Corrupção Passiva de Caixa Dois, tendo em vista os envolvidos na operação. (MATOS FILHO, 2017).

Antes de adentrarmos especificamente na distinção, necessário retomar o conceito de "delação premiada" a fim de sanar eventuais dúvidas sobre o termo. Nesse sentido,

[...] a delação foi na linguagem forense mais propriamente para designar a denúncia de um delito, praticado por pessoa, sem que o denunciante (delator) se mostre parte interessada diretamente na sua repressão [...]. Ao lado dessa modalidade de delação, surgiu uma outra seguida do adjetivo "premiada" que é implicativa de recompensa. Disso resulta que essa modalidade de delação é utilizada por pessoa envolvida no delito e

25 BRASIL. Tribunal Superior Eleitoral. HC n 00079945720146190000 , Cabo Frio/RJ, acórdão de 10/02/2015, da relatoria da ministra Maria Thereza Rocha de Assis Moura. 
que procura obter o benefício da redução ou mesmo isenção das penas respectivas, na dependência de norma e respeito. (MOSSIN, 2018, p. 40).

Neste passo, resta claro que Emílio Odebrecht fez parte do grande escândalo conhecido como "Lava Jato" e, a fim de ter uma redução em sua pena, fez uso da delação premiada. Com isso, passaremos a analisar os dois crimes em questão, quais sejam, Corrupção Passiva e Caixa Dois.

Com relação à semelhança entre os delitos podemos citar a classificação de ambos no chamado "crime formal", que, conforme mencionado anteriormente, é conceituado por Capez (2018, p. 282) como o "delito que não exige a produção do resultado para sua consumação, portanto, o resultado, embora possível, é irrelevante para consumação da infração penal".

No que concerne à diferença entre os delitos, podemos citar o fato de a Corrupção Passiva ser um crime próprio, tendo em vista a limitação face aos sujeitos ativos da infração no caso, para que incida no artigo 317 do Código Penal, necessário o cometimento do ato por funcionário público.

Diante disso, Matos Filho faz a seguinte observação sobre a principal diferença dos crimes:

A principal diferença entre esses tipos penais reside mesmo na intenção do funcionário público. Se foi "apenas" uma doação recebida para o fim de custear a campanha eleitoral (em geral, representa uma forma de lobby), cujo valor não foi contabilizado, ou foi contabilizado com informações falsas, teremos o dito caixa dois. Todavia, se o funcionário público recebe, solicita ou aceita a promessa de uma dada benesse indevida, para si ou para outrem, direta ou indiretamente, ainda que fora da função ou antes de assumi-la, mas em razão dela, por já ter prestado ou ao menos com a intenção de prestar prática, omissão ou retardação de ato de ofício, infringindo dever funcional, teremos a corrupção passiva. (MATOS FILHO, 2017, p. 5).

A intenção do funcionário será o principal determinante para caracterização do delito, pois quando estivermos falando de uma doação feita por funcionário público, cuja finalidade seja custeio de campanha eleitoral, de modo geral, representa uma forma de $l o b b y^{26}$, deixando de ser o valor doado contabilizado, ou, até mesmo quando houver contabilização de maneira fraudulenta, estaremos diante do Caixa Dois. Entretanto, quando o servidor público recebe, solicita ou aceita a promessa de um favorecimento indevido (condutas previstas no artigo 317 do Código Penal), direta ou indiretamente, mesmo fora da função, ou antes de assumi-la, mas em razão dela, a infração do dever funcional caracterizará a Corrupção Passiva. (MATOS FILHO, 2017).

26 Grupo de pessoas, físicas ou jurídicas, que se organizam em torno de um objetivo em comum e tentam interferir nas decisões dos poderes Executivo e Legislativo, para que as decisões coincidam com seus interesses. 
Para a configuração do delito previsto no artigo 317 do Código Penal não irá importar "se o funcionário público recebeu as vantagens por meio de caixa um (doações devidamente contabilizadas) ou Caixa Dois, pois a Corrupção Passiva estará caracterizada do mesmo modo". (MATOS FILHO, 2017, p. 2).

Isto é, a infração intitulada Caixa Dois acontecerá sempre em um contexto eleitoral, diferentemente da Corrupção Passiva, a qual poderá ocorrer tanto em âmbito eleitoral, como não.

Matos Filho (2017, p. 4) faz a seguinte ressalva quanto à Corrupção Passiva:

[...] nem todo valor recebido ilegalmente por funcionário público é crime de corrupção passiva. Pode ser, por exemplo, que o funcionário tenha recebido um valor proveniente de infração legal com o objetivo único de ocultar ou dissimilar sua natureza ou origem, e nessa situação teríamos exclusivamente o crime de lavagem de dinheiro.

Neste passo, é possível verificar que os tipos penais deverão ser analisados de acordo com todos os seus elementos, pois, nem sempre estaremos diante de uma Corrupção Passiva só por tratar-se de recebimento de valor. Podemos estar diante de uma Lavagem de Dinheiro, conforme supracitado, mas nunca será possível confundir a Corrupção Passiva com o Caixa Dois.

Como relatado no início deste item, a delação de Emilio Odebrecht abriu as portas para a expansão do Caixa Dois. Tal informação se faz perceptível quando analisamos a informação aludida por Falcão (2017, p. 1), "entre os 76 inquéritos abertos pelo STF a partir da delação da Odebrecht, 31 congressistas são suspeitos de terem praticado o Caixa Dois puro, ou seja, irregularidade eleitoral sem indícios de conexão com outros crimes, como a corrupção ou lavagem de dinheiro". (grifo nosso).

Ora, inexistem dúvidas de quão obscuro ficou o cenário político após tais eventos e, quão desafiante se tornou o reconhecimento do Caixa Dois, motivo pelo qual se faz necessário reiterar o item anterior, tendo em vista, inclusive, posição do ministro Gilmar Mendes ao afirmar o seguinte: "o Judiciário tem duas interpretações sobre o tema. Uma que pune o Caixa Dois como crime e a outra que trata a prática como "atípica", ou seja, não prevista na legislação como crime" (SCOCUGLIA, 2016, p. 1), ressaltando que a afirmação fora feita em 2015, antes mesmo do aumento significativo de investigações sobre o tema.

Diante de tantas incertezas sobre qual tipificação deverá ser incidida ao delito, a Procuradoria Geral da República buscou meios para conseguir identificar a distinção, por meio dos depoimentos.

Importante ressaltar, entretanto, a zona cinzenta mencionada por Recondo (2017, p. [1]):

Há, porém, uma zona cinzenta, e os procuradores e advogados admitem isso. Há um grupo de políticos contra os quais há indícios suficientes da prática de corrupção disfarçada de contribuição de campanha. Há um segundo grupo de parlamentares, ministros e governadores que nitidamente receberam caixa dois eleitoral, sem sinal da prática de corrupção. 
E há um terceiro espaço - aqui está a zona cinzenta - em que ainda é impossível saber exatamente para que serviria o dinheiro repassado.

Diante de tais complicações, os procuradores tentaram manter um roteiro de perguntas ao chamarem diretores, ex-diretores e funcionários da Odebrecht para depor, de modo a conduzir o questionário e conseguir identificar qual tipificação era adequada à doação feita pela empresa. As questões eram feitas do seguinte modo:

Primeiro, os procuradores questionavam se o delator deu dinheiro para a campanha. Depois, indagavam se ele saberia dizer quais foram os gastos de campanha quitados com aquele recurso. Em qual conta o dinheiro foi depositado? Na conta do partido? Na conta da campanha? Em vários casos, a conta indicada para o depósito não foi do candidato ou da legenda, mas uma conta de titular desconhecido, indicada pelo arrecadador de campanha, por exemplo. Vinha em seguida uma pergunta, atrelada à anterior, cuja resposta era quase sempre negativa: você, delator, consegue assegurar que o dinheiro foi mesmo para a campanha? Neste ponto, vários dos diretores, ex-diretores e funcionários da Odebrecht disseram algo semelhante: o dinheiro foi pedido como se fosse para campanha, mas que não sabiam se a destinação foi realmente aquela. Os procuradores perguntavam ainda por que a empresa doava dinheiro antes da campanha eleitoral e depois da eleição. E alguns dos delatores disseram que havia antecipação de doações e, terminada a corrida eleitoral, pagamento das despesas restantes da campanha. (RECONDO, 2017, p. 2).

Nesse sentido, é possível deduzir a dificuldade em especificar os delitos, motivo pelo qual se faz necessário seguir esse roteiro, a fim de distinguir se a conduta foi de mera liberalidade da empresa ou, se houve a solicitação e atuação de ofício do político. Tratando-se do segundo caso, estaremos diante da Corrupção Passiva, pois a "contraprestação à realização ou abstenção de algum ato de competência específica do funcionário público (ato de ofício)" (CAPEZ, 2014, p. 442) é elemento do tipo penal.

\subsection{DECISÃO DO STF}

Em 2017 o Supremo Tribunal Federal, na petição 7.038 de relatoria da ministra Rosa Weber autorizou a instauração de inquérito penal para apurar prática de delito cometido pelo então senador José Serra. Importante levar em conta a data de deferimento do pedido, tendo em vista a prerrogativa de foro perante o Supremo Tribunal Federal, nos termos dos artigos 53, $\$ 1^{\circ}$ e 102 , I, b da Constituição Federal. O primeiro dispositivo legal dispõe que deputados e senadores serão submetidos a julgamento perante o Supremo Tribunal Federal ${ }^{27}$, e o segundo menciona a competência da Corte para julgar os membros do Congresso Nacional nas infrações penais comuns ${ }^{28}$. 
O requerimento formulado pelo procurador geral da República foi embasado em trechos do depoimento de Joesley Mendonça Batista, no momento em que firmou acordo de colaboração premiada com o Ministério Público Federal. Em resumo, eis o trecho fundamental para o requerimento:

[...] Joesley afirmou, em resumo, ter acertado pessoalmente com o Senador José Serra uma contribuição de R $\$ 20.000 .000,00$ (vinte milhões de reais) para a campanha presidencial de 2010, dos quais aproximadamente $\mathrm{R} \$ 13.000 .000,00$ (treze milhões de reais) teriam sido contabilizados na prestação de contas do PSDB (doação oficial), e aproximadamente R\$ 7.000.000,00 (sete milhões de reais), teriam sido pagos de forma inoficiosa ("caixa dois"), da seguinte maneira: (i) nota fiscal superfaturada de aquisição de camarote em um autódromo para evento de Fórmula 1, emitida pela empresa LRC Eventos, supostamente ligada a um indivíduo chamado Forquin, amigo do Senador José Serra, (ii) emissão de "nota fiscal fria" no valor de $\mathrm{R} \$ 420.000,00$ (quatrocentos e vinte mil reais), emitida pela empresa APPM Análises e Pesquisas ${ }^{29}$ (grifos do relator).

Após tais informações o procurador geral da República justificou a investigação como forma de verificar possível ocorrência do delito tipificado no artigo 35 do Código Eleitoral.

Neste passo, por inexistirem causas excludentes da ilicitude do fato, bem como da culpabilidade do possível investigado, a ministra deferiu o pedido e autorizou a instauração do inquérito para investigação dos fatos relacionados à conduta do senador.

No entanto, em 28 agosto de 2018, por unanimidade, a Segunda Turma do Supremo Tribunal Federa determinou a remessa dos autos do Inquérito Policial (INQ 4428) para a Justiça Eleitoral, fixando o entendimento de que a prerrogativa de foro é limitada aos crimes praticados durante o exercício do cargo e relacionado às funções desempenhadas, motivo pelo qual inviável seria a tramitação do inquérito no Supremo Tribunal, tendo em vista o crime apurado ter sido durante o mandado de governador do estado de São Paulo.

\subsection{Julgamento Pela Justiça Eleitoral}

A discussão sobre a quem compete julgar crimes de Corrupção e Caixa Dois quando cometidos em conexão ${ }^{30}$ não é de hoje e se dá devido à autonomia de ambos.

Neste passo, prevê o artigo 78, IV do Código de Processo Penal que, quando estivermos diante de concurso de crimes entre a jurisdição comum e a especial, irá prevalecer a especial. Ou seja, havendo conexão entre a Corrupção (crime de competência da Justiça Comum) e o Caixa Dois (competência da Justiça Eleitoral), seria a Justiça Eleitoral competente para o todo.

29 Decisão referente à Petição 7.038 Distrito Federal. Supremo Tribunal Federal. Relatoria da ministra Rosa Weber, datado de 18/08/2017

30 Configura-se quando houver uma ligação entre as infrações penais, ou seja, se revela como unificação de processos que possuem, entre si, alguma espécie de vínculo. 
Neste passo, importante expor o pensamento de Silvana Batini (2019, p. 3):

\begin{abstract}
Desde que a Lava Jato escancarou as vinculações profundas entre corrupção e financiamento de campanhas, nunca se cogitou mandar os processos para a justiça eleitoral. O bom senso prevaleceu ao longo de todos os anos e os processos vêm tramitando na justiça comum federal, sem qualquer questionamento. Investigações criminais complexas demandam tempo, estabilidade e especialização. A Lava Jato jamais teria chegado onde chegou se tivesse que tramitar na justiça eleitoral, justamente porque esta não reúne nenhuma daquelas condições. Não é uma justiça especializada em processos criminais, voltada que está aos conflitos eleitorais. Seus juízes fazem rodízio a cada dois anos; seus tribunais também têm composição transitória, e ainda contam, nos colegiados, com advogados-juízes que não têm as mesmas garantias e limitações da magistratura togada. O Ministério Público Eleitoral tampouco tem estrutura de investigação de crimes complexos, e seus membros também cumprem mandato de 2 anos. São fatores que impedem ciclos investigativos longos e ramificados. (grifo nosso).
\end{abstract}

Ora, o julgamento pela Justiça Comum implicaria também em penas mais gravosas, motivo pelo qual muitos advogados pleiteiam na Justiça a remessa dos autos à Justiça Eleitoral.

Em que pese não haver definição da Justiça competente, muitos dos autos eram remetidos à Justiça Eleitoral, tendo em vista a especificidade do delito.

Neste passo, o Supremo decidiu sobre o tema, sendo a competência da Justiça Eleitoral para julgar crimes comuns conexos a delitos eleitorais.

No entanto, antes do julgamento, mais precisamente em março de 2019, o ex-ministro da Justiça e Segurança Pública, Sergio Moro ${ }^{31}$, se posicionou afirmando a insuficiência da Justiça Eleitoral para julgar processos complexos, quais sejam, aqueles que envolvam Corrupção ou Lavagem de Dinheiro, tendo em vista a ausência de estrutura da Justiça em questão. Portanto, na visão do ministro o ideal seria a separação de competências, permanecendo o delito de Caixa Dois na Justiça Eleitoral e, paralelo a isso, sendo julgado o delito de Corrupção Passiva pela Justiça Federal.

Por conseguinte, em 13 de março de 2019 o plenário do Supremo Tribunal Federal (STF) iniciou o julgamento do Agravo Regimental interposto por investigados no Inquérito Policial (INQ) 4435 (investigação decorrente das informações obtidas nas delações premiadas). O julgamento tinha por objetivo decidir sobre a competência de crimes comuns conexos a crimes eleitorais.

Tendo por fim, o plenário do STF definido como competente a Justiça Eleitoral para julgar os crimes comuns conexos aos delitos eleitorais, sendo a corrente majoritária dos votos composta pelo ministro-relator Marco Aurélio, Alexandre de Moraes, Ricardo Lewandowski, Gilmar Mendes, Celso de Mello e Dias Tof-

31 Ficou conhecido nacionalmente ao atuar nos processos da Lava Jato, sendo o Juiz responsável por julgar o caso. Pediu exoneração para assumir o Ministério da Justiça. 
foli. A maioria dos ministros acompanhou o voto do relator, que considerou a competência da Justiça Eleitoral. O ministro Gilmar Mendes, ao proferir o voto, fez uma análise histórica constitucional, avaliando que as Constituições de 1932, 1934, 1946, 1967 e 1969 reconhecem a competência da Justiça especializada para processar e julgar Crimes Eleitorais e conexos, ressaltando que isso demonstra a continuidade normativa, afirmando que a Constituição Federal de 1988 não tratou da questão de forma taxativa, mas seu artigo $121^{32}$ segue a linha de raciocínio das Constituições anteriores.

O ministro Celso de Mello, ao proferir seu voto, destacou que a jurisprudência da Corte tem sido muito clara, embasando-se na Constituição da República Federativa. No mesmo sentido, votou o ministro Ricardo Lewandowski.

O presidente do STF, ministro Dias Toffoli, destacou que todos estavam ali unidos no combate à corrupção e em defesa da Justiça Eleitoral, que estará pronta para atuar, reiterando seus votos proferidos à época em que integrava a Segunda Turma e, seguem a linha da jurisprudência da Corte.

Já os ministros Edson Fachin, Luís Roberto Barroso, Rosa Weber, Luiz Fux e Carmen Lúcia, tiveram seus votos vencidos ao defenderem a fragmentação de parte da apuração entre a Justiça Eleitoral e a Justiça Federal.

O ministro Edson Fachin foi o primeiro a divergir e em seu voto justificou que deveria ser encaminhada uma cópia dos autos à Justiça Eleitoral para prosseguimento de julgamento do delito exclusivamente eleitoral e, quanto aos demais delitos, a competência deveria ser da Justiça Federal, explicando que os órgãos deveriam ser julgados por órgãos distintos. Segundo Fachin, "havendo concorrência de juízos com competências igualmente fixadas na Constituição Federal, o caminho a ser tomado para a observância do princípio do juiz natural é cisão do processo" ${ }^{33}$.

O ministro Luís Roberto Barroso divergiu da corrente majoritária, justificando que, casos conexos deveriam ser iniciados na Justiça Federal e, somente no final deveria ser definido o local de encaminhamento dos autos (a depender dos crimes envolvidos).

O ministro Luiz Fux seguiu o voto do ministro Edson Fachin, defendendo que a competência seja definida somente no fim da investigação, após conclusão da imputação dos crimes pelo Ministério Público.

As ministras Rosa Weber e Carmen Lúcia acompanharam os ministros supracitados, divergindo da corrente majoritária.

Diante disso, até a data de entrega do presente artigo (12 de julho de 2020), podemos afirmar que os delitos conexos a Crimes Eleitorais serão de competência da Justiça Eleitoral.

32 Lei complementar disporá sobre a organização e competência dos Tribunais, dos juízes de direito e das Juntas Eleitorais.

33 QUARTO AG.REG. NO INQUÉRITO 4.435 DISTRITO FEDERAL. Acórdão proferido em 14/03/2019. Disponível em: http://redir.stf.jus.br/paginadorpub/paginador.jsp?docTP=TP\&docID $=750577279$ 


\section{CONSIDERAÇÕES FINAIS}

Este artigo teve por objeto de estudo a distinção entre a Corrupção Passiva e o Caixa Dois, sendo que esta pesquisa foi motivada pelos escândalos recorrentes e atuais entre os partidos políticos e grandes empresas, em que se viu necessário distinguir os conceitos.

Com a pesquisa, conclui-se que o delito da Corrupção Passiva passou a vigorar após definição do Código Penal de 1940, sendo, portanto, uma tipificação antiga, mas ainda assim recorrente.

Ao prever a Corrupção Passiva o legislador se preocupava com o regular funcionamento da Administração Pública - desta forma, toda e qualquer violação à Carta Magna será punida, motivo pelo qual os princípios do artigo 37 da Constituição Federal não podem ser violados, a fim de que não fique caracterizado o delito.

O cenário atual entra em conflitos constantemente, pois, muito embora mais fácil fosse tipificar todos os crimes políticos praticados como Corrupção Passiva, o órgão legiferante não podem fazer isso.

Ora, após escândalos envolvendo os maiores partidos políticos do país, nos vimos diante do contexto mencionado, no qual a figura do Caixa Dois emergiu face aos demais delitos, devido principalmente ao fato de as delações premiadas serem firmadas nesse período.

Neste passo, com relação ao Caixa Dois pode-se concluir que a maior dificuldade seria a de tipificar o crime, tendo em vista a inexistência de previsão legal, conforme mencionado, motivo pelo qual, quando caracterizada a prática de Caixa Dois, esta será enquadrada como a conduta prevista no artigo 350 do Código Eleitoral (falsidade ideológica).

Destarte, após pesquisa para realização deste trabalho, consideramos importante e necessária a criação de tipificação específica para o delito, pois sua eventual tipificação poderia resultar na queda da prática desta ação, pois as pessoas iriam ter ciência do risco que estão assumindo e não lidariam apenas com a incursão no crime de falsidade ideológica eleitoral.

Ademais, para distinguir ambos os delitos importante analisar o fato no geral, pois a conduta do funcionário público será elemento essencial para a caracterização do feito - ou seja, se este solicitar, receber ou aceitar promessa de receber vantagem indevida, estaremos diante de Corrupção Passiva, delito cuja pena imposta é a reclusão de 2 a 12 anos e multa. Já para que seja reconhecida a prática de Caixa Dois, o crime deverá ser cometido no âmbito eleitoral e neste caso o agente será incurso no artigo 350 do Código Eleitoral e terá a pena de reclusão até 5 anos e pagamento de 5 a 15 dias-multa, tratando-se de documento público e reclusão de até 3 anos e pagamento de 3 a 10 dias-multa em caso de documento particular. Caso a omissão não seja em âmbito eleitoral estaremos diante do artigo 299 do Código Penal, por isso se faz necessária a análise dos fatos de maneira criteriosa.

Por fim, com relação à conexão dos crimes, entendemos que delimitar a competência para a Justiça Eleitoral é um retrocesso, pois a pena prevista para aquele que comete Corrupção Passiva chega a ser 4 vezes maior do que a pena prevista no 
artigo 350 do Código Eleitoral, tendo em vista tratar-se de reclusão de 2 a 12 anos e multa $^{34}$. Neste passo, presumimos que delimitar a competência e fragmentá-la seria conduta mais apropriada, ou seja, manter o julgamento do crime de corrupção na Justiça Federal e, em paralelo, julgar o delito de Caixa Dois na Justiça Eleitoral, pois uma "punição" mais rigorosa faria com que a prática deixasse de ser rotineira. Assim sendo, se o país deseja seguir o previsto em sua própria Constituição, deve buscar meios eficientes para combater a corrupção e minimizar a prática do Caixa Dois, conduta essa exercida muita das vezes pelos nossos próprios governantes.

\section{REFERENCIAS}

AGUIAR, Adriana. Anteprojeto prevê mais rigor contra crime eleitoral. Consultor Jurídico. Disponível em: https://www.conjur.com.br/2005-nov-22/anteprojeto_preve_rigor_ crime_eleitoral. Acesso em: 20/05/2019.

ALVES SOBRINHO, Rogério de Souza Alves. O Tratamento Jurídico-Penal da Corrupção Administrativa Sob a Perspectiva do Direito Comparado. Revista Transgressões - Ciências Criminais em Debate. 2015. Disponível em: https:/ / periodicos.ufrn.br/transgressoes/article/view/6961/5359. Acesso em: 14/03/2019.

BATINI, Silvana. Corrupção e caixa 2: Justiça Eleitoral ou Comum? Disponível em: https:/ / www.jota.info/stf/supra/corrupcao-e-caixa-2-justica-eleitoral-ou-comum-08032019. Acesso em: 24/05/2019.

BEM, Leonardo Schmitt de; CUNHA, Mariana Garcia. Direito Penal Eleitoral: Análise Constitucional dos Delitos Eleitorais; comentários à Lei da Ficha Limpa. 2. ed. São Paulo: Conceito Editorial. 2011.

BLUME, Bruno André. Corrupção Ativa e Corrupção Passiva: Qual a diferença? Politize! Disponível em: https://www.politize.com.br/corrupcao-ativa-e-corrupcao-passiva/. Acesso em: 21/03/2019.

BRASIL. Código Criminal do Império. Lei 16 de dezembro de 1830. Planalto. Disponível em: http://www.planalto.gov.br/ccivil_03/leis/lim/LIM-16-12-1830.htm. Acesso em: 26/04/2019.

BRASIL. Código Eleitoral. Lei n. 4.737, de 15 de julho de 1965. Planalto. Disponível em: http://www.planalto.gov.br/ccivil_03/leis/14737.htm. Acesso em 10/05/2019.

BRASIL. Código Penal. Decreto-Lei n. 2.848/1940. Planalto. Disponível em: http://www. planalto.gov.br/ccivil_03/decreto-lei/del2848compilado.htm. Acesso em: 25/04/2019.

34 Artigo 317 do Código Penal. 
BRASIL. Constituição da República Federativa do Brasil de 1988. Planalto. Disponível em: http://www.planalto.gov.br/ccivil_03/constituicao/constituicao.htm. Acesso em: 02/05/2019.

BRASIL. Crimes contra a ordem tributária. Lei n. 8.137/1990. Planalto. Disponível em: http:/ / www.planalto.gov.br/ccivil_03/leis/18137.htm. Acesso em: 02/05/2019.

BRASIL. Crimes contra o sistema financeiro nacional. Lei n. 7.492/1986. Planalto. Disponível em: http:/ / www.planalto.gov.br/ccivil_03/leis/17492.htm. Acesso em: 02/05/2019.

BRASIL. Decreto n. 847. Câmara dos Deputados. Disponível em: https:/ / www2.camara. leg.br/legin/fed/decret/1824-1899/ decreto-847-11-outubro-1890-503086-publicacaooriginal-1-pe.html. Acesso em: 15/03/2019.

BRASIL. Supremo Tribunal Federal. Inquérito 4428. Disponível em: http:/ / portal.stf.jus. br/processos /detalhe.asp?incidente=5149796. Acesso em: 24/05/2019.

BRASIL. Supremo Tribunal Federal. Inquérito sobre suposto caixa 2 de campanha de José Serra será remetido à Justiça Eleitoral. Disponível em: http://www.stf.jus.br/portal/ cms/verNoticiaDetalhe.asp?idConteudo=388196. Acesso em: 24/05/2019.

BRASIL. Supremo Tribunal Federal. Plenário do STF reafirma competência da Justiça Eleitoral para julgar crimes comuns conexos a delitos eleitorais. Disponível em: http:/ / www.stf.jus.br/portal/cms/verNoticiaDetalhe.asp?idConteudo $=405834$. Acesso em: 25/05/2019.

BRASIL. Tribunal Superior Eleitoral. HC 0007994-57.2014.6.19.0000. Disponível em: https://tse.jusbrasil.com.br/jurisprudencia/468982516/habeas-corpus-hc-79945720146190000-cabo-frio-rj?ref=serp. Acesso em: 16/05/2019.

BRASIL. Tribunal Superior Eleitoral. HC n. 0000214-60.2015.6.00.0000. Disponível em: http:/ / inter03.tse.jus.br/sadpPush/ExibirDadosProcessoJurisprudencia.do?npro$\mathrm{c}=21460 \&$ sgcla $=$ HC\&comboTribunal $=$ tse\&dataDecisao $=02 / 08 / 2016$. Acesso em: $17 / 05 / 2019$

BRASIL. Tribunal Superior Eleitoral. RESPE 0002675-60.2010.6.21.0011. Disponível em: https://tse.jusbrasil.com.br/jurisprudencia/576310345/recurso-especial-eleitoral-respe-26756020106210011-portao-rs?ref=serp. Acesso em:16/05/2019.

CAPEZ, Fernando. Curso de Direito Penal: Parte geral - 1. 18. ed. São Paulo: Saraiva Jur. 2014. 
CAPEZ, Fernando. Curso de Direito Penal: Parte especial - Arts. 213 a 359-H. 15. ed. São Paulo: Saraiva Jur. 2017.

CAPEZ, Fernando. Curso de Processo Penal. 25. ed. São Paulo: Saraiva. 2018

CASTILHOS, Angelo Soares. Caixa 2 eleitoral. Revista Jus Navegandi. Disponível em: https:/ /jus.com.br/artigos/64243/caixa-2-eleitoral. Acesso em: 16/05/2019.

CAZARRÉ, Carlos Augusto da Silva; KANAAN, Alice. Temas de Direito Eleitoral no Século XXI. Brasília: Escola Superior do Ministério Público da União. 2012. Disponível em: http:/ / escola.mpu.mp.br/publicacoes/obras-avulsas/e-books-esmpu/temas-de-direito-eleitoral-no-seculo-xxi

D'OLIVEIRA, Heron Renato Fernandes. A história do direito penal brasileiro. Revista Faculdade Projeção. São Paulo. 2014. Disponível em:

http:/ / revista.faculdadeprojecao.edu.br/index.php/Projecao2/article/viewFile/410/367

DUTRA, Fábio; GUIMARÃES, Paulo; ARAÚJO, Renan. Lei 8.137/1990 Comentada e Esquematizada para Concursos Públicos. Estratégia Concursos. Disponível em: https:// www.estrategiaconcursos.com.br/blog/lei-8137-90-comentada-e-esquematizada/. Acesso em 10/05/2019. Acesso em: 20/05/2019

FALCÃO, Márcio. PGR discute alternativas para caixa 2 "puro" na Lava Jato. Disponível em: https://www.jota.info/justica/pgr-discute-alternativas-para-caixa-2-puro-na-lava-jato-25042017. Acesso em: 16/05/2019.

FAZZIO JUNIOR, Waldo. Fundamentos do Direito Administrativo. 2. ed. São Paulo: Atlas. 2001.

GOMES, Luiz Flavio. Caixa 2 eleitoral é crime? Jusbrasil. Disponível em: https:/ / professorlfg.jusbrasil.com.br/artigos/204315523/caixa-2-eleitoral-e-crime. Acesso em: 11/05/2019

GOMES, Suzana de Camargo. Crimes Eleitorais. 3. ed. São Paulo: Revista dos Tribunais. 2008.

GONÇALVES, Luiz Carlos dos Santos. Crimes Eleitorais e Processo Penal Eleitoral. 2. ed. São Paulo: Atlas. 2015.

HABIB, Sérgio. Brasil: Quinhentos anos de corrupção. São Paulo: Editora Sérgio Antônio. 1994. 
LIZST, Franz Von. Tratado de Direito Penal Alemão. Disponível em: http:/ / www2.senado.leg.br/bdsf/handle/id/496219. Acesso em: 11/05/2019.

MAQUIAVEL, Nicolau. Discursos sobre a primeira década de Tito Lívio. São Paulo: Martins Fontes, 2007.

MATOS, Aline Suélen Farias; BARBOZA, Luís Cesar do Carmo. CORRUPÇÃO NO PODER PÚBLICO BRASILERIO: a impunidade diante da imunidade parlamentar prisional. Revista Fadivale. Ano XIII, nº 14. Governador Valadares. 2017.

MATOS FILHO, Renato de Souza. A distinção dos crimes de corrupção passiva e caixa dois no contexto da delação de Emílio Odebrecht. Revista Jus Navegandi. Disponível em: https://jus.com.br/artigos/58034/a-distincao-dos-crimes-de-corrupcao-passiva-e-caixa-dois-no-contexto-da-delacao-de-emilio-odebrecht. Acesso em: 26/04/2019.

MOSSIM, Heráclito Antonio; MOSSIN, Julio Cesar O. G. Delação Premiada - Aspectos Jurídicos. 3. ed. São Paulo: J.H. Mizuno. 2018.

NUCCI, Guilherme de Souza. Código Penal Comentado. 16. ed. São Paulo: Forense. 2016.

PIAZER, João Batista Martins. A figura típica do caixa dois eleitoral. Orientador: Ângelo Roberto Ilha da Silva. 2015. 62 folhas. Bacharel em Ciências Jurídicas e Sociais. Universidade Federal do Rio Grande do Sul, Porto Alegre.

PONTE, Antonio Carlos da. Crimes Eleitorais. 2. ed. São Paulo: Saraiva, 2016.

REALE JUNIOR, Miguel. Teoria do Delito. 2. ed. São Paulo: Revista dos Tribunais. 2000.

RECONDO, Felipe. Como a PGR distingue corrupção de caixa dois? Disponível em: https:// www.jota.info/opiniao-e-analise/artigos/como-a-pgr-distingue-corrupcao-de-caixa-dois-10032017. Acesso em: 20/05/2019.

SCHLICKMANN, Denise Goulart; LUBKE, Heloísa Helena Bastos Silva. Financiamento de campanhas eleitorais: avaliação das proposições apresentadas pelo Tribunal Superior Eleitoral ao Congresso Nacional. Resenh@eleitoral. Disponível em: http:/ /www.tre-sc. jus.br/site/resenha-eleitoral/revista-tecnica/edicoes-impressas/integra/2012/06/financiamento-de-campanhas-eleitorais-avaliacao-das-proposicoes-apresentadas-pelo-tribunal-superior-eleitoral-ao-congresso-nacional/index1225.html?no_cache=1\&cHash=86eb7a536c4e0695c4268006fd667d30. Acesso em: 11/05/2019. 
SCOCUGLIA, Livia. Gilmar Mendes defende regulamentação do crime de Caixa Dois. JOTA. Disponível em: https://www.jota.info/justica/gilmar-mendes-defende-regulamentacao-crime-de-caixa-dois-20092016. Acesso em: 16/05/2019.

STRECKER, Heidi. Jean-Jacques Rousseau (1) - O contrato social. Uol Educação. Disponível em: https://educacao.uol.com.br/disciplinas/filosofia/jean-jacques-rousseau-1-o-contrato-social.htm. Acesso em: 28/02/2019.

TEIXEIRA, Juliana Ferrer. Corrupção passiva: análise do artigo 317 do Código Penal e sua relação com as Leis n. 8.429/92, n. 9.034/95 e n. 9.613/98. Orientador: Dirceu de Mello. 2010. 181 folhas. Mestrado em Direito Penal. PUC, São Paulo, 2010.

XAVIER, Carlos Joel Carvalho de Formiga. A corrupção política e o caixa 2 de campanha no Brasil. Orientador: José Álvaro Moisés. 2010. 117 folhas. Mestrado em Ciência Política. Universidade de São Paulo, São Paulo, 2010. 